\title{
The Problems of Economic Development among the Hiras, an Occupational Caste of Assam

\author{
Barasha Rani Baishya
}

\begin{abstract}
Assam, the fascinating land of blue hills and red rivers, is inhabited by a number of communities belonging to various ethnic origins with diverse cultures. These communities can broadly be divided into two categories viz. tribals and nontribals and they are found spread on the hills as well as the two valleys of the state. The non-tribal category of inhabitants can again be sub-divided into high caste Hindus, O.B.C.'s, M.O.B.C.'s and Scheduled Castes (SC). Numerically, Hiras occupy the fifth position among the Scheduled Caste of Assam. They are traditionally an occupational Caste who make pottery by means of hand. Economic backwardness of the Hiras can be attributed to their low income occupation. The people should be made realize that education is the only way to equip oneself for Socio-economic development.
\end{abstract}

Keywords: Occupational Caste, Hiras, Pottery making industry, Socio-Economic backwardness \& development.

\section{INTRODUCTION}

Before addressing the problems of the scheduled castes (SC) in Assam, it is worthwhile to know who the scheduled castes are. According to the scheduled castes and scheduled tribes Orders (Amendments) Act, 1976 there are sixteen sub-caste in Assam. These are i) Bansphor ii) Bhuinmali Mali iii) Brittial-Bania iv) Dhupi Dhobi v) Dugla, Dholi vi) Hira vii) Jalkeot viii) Jhalo,Malo ix) KaibartaJaliya $\mathrm{x}$ ) Lalbegi xi) Mahara xii)Mehtar, Bhangi xiii) Muchi, Rishi xiv) Namasudra xv) Patni xvi) Sutradhar.

The Hiras are a major scheduled caste of Assam. They are traditionally an occupational caste who make pottery by means of hand. In the caste hierarchy, they occupy a very low positionwhich is even lower than that of the kumars who manufacture pottery by means of the wheel. The people of this class use special type of clay which is found only in Assam and which is popularly called as 'HIRA CLAY', A principal raw material of the pottery industry of Assam. That is why, this potters group is distinguished as the Hira potters or Hira Community in Assam. They produce various kinds of earthen pots and utensils of the best quality for households and community use. They usually manufacture the potteries as per the demand of the locality.

\section{LITERATURE REVIEW}

Many scholars have tried to devise an occupational scale to study the occupational mobility among the societies. North and Halt (1961) have formulated some basic aspects like income, education, training or the combination of all these three for studying the occupational mobility of a community.

Revised Manuscript Received on March 13, 2020.

* Correspondence Author Assam.

Barasha Rani Baishya*, Research Scholar, Cotton University,

(C) The Authors. Published by Blue Eyes Intelligence Engineering and Sciences Publication (BEIESP). This is an open access article under the CC BY-NC-ND license (http://creativecommons.org/licenses/by-nc-nd/4.0/)
They have found that the rating of an occupation depends on public opinion. It is difficult to judge the public opinion of an occupation in time and space. Moreover, the status of occupation may also change from time to time.

Therefore, the authors opinion about the occupation mobility does not hold good in our present study. Huges (1958) calls it group mobility. He has shown how the transfer of dirty work to lesser dirty occupation has caused an upward mobility of an occupation. Miller and Form (1964) stated that the change over of an occupational group to another depends on the market demand. Davidson and Anderson (1937) have studied occupational mobility of an American Community. They found that in the United States, there was less occupational mobility among the communities. Saraswati and Behura (1966) have studied some of the potter castes in India. They found the social status of the potters is not uniform all over India. They further referred that the diversity in the social hierarchy occurs not only in different linguistic areas but difference occurs in the same linguistic zone. Majumdar and Datta Ray (1984) have studied the occupational mobility among the Khasis, the Garos and the Jaintias of Meghalaya. All these three tribal groups are matrilineal and trace their descent through the female line. But in the occupational structure, females occupy a less important position. Further, the authors have pinpointed that in all the three major towns (Shillong, Jowai and Tura) of Meghalaya there is a scramble of the moderately educated people for the office jobs. While studying the occupational change among the scheduled castes of Assam, Sharma Thakur (1985) opines that the Kaibartas, major Scheduled Caste of Assam, are basically fisherman but at present, they have switched over to agriculture. Mrinmoyee Bhattacharyya (2014) reflects socioeconomic condition of Hira Community in his research thesis titled "Socio-Economic condition of Hira Community-a case study of Kamrup district of Assam". We fell that judging from our empirical experience the above works along with their defined characteristics cannot be applied as fixed model to our study. However, the above works help us to understand the socio-economic problems of different communities. It is to be noted here that unlike the Kaibartas the Hiras have not taken up agriculture as a prime mode of occupation. However, alongwith the pottery making they have also taken up some other jobs to survive.

\section{THEOROTICAL BACKGROUND}

\subsection{POPULATION}

We may now ask what the size of the SC population is. The total population of Assam in 2001 Census has been 26, 655, 528 (2.67 Crore). Of them, 1,825,949 persons are Scheduled Castes (SC's), constituting 6.9 percent of the total population of the state.

\section{Published By:}

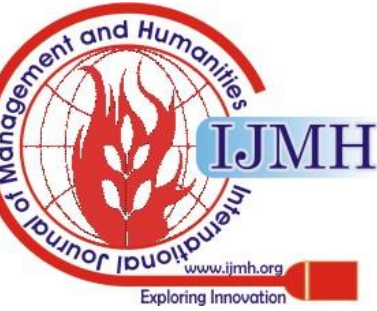


That state has registered 10 percent decadal growth of SC population in 1991-2001.There are sixteen notified SC's and all have been enumerated in 2001 Census. 25 percent of the SC's are living in rural areas.

Individual SC wise there is wide variation with regard to their rural-urban distribution of population. A high of 27.9 percent urban population has been recorded among Dhupi, followed by Brittial Bania with23.3 percent. On the contrary, Patni has recorded the lowest of 7.3 percent urban population Namasudra, Hira, Muchi and Kaibarta are predominantly residing in rural areas having more than 85 percent rural population.

According to 2011 census, 82 percent of the Schedule Caste population in Assam is living in rural areas. However, community wise there is wide variation with regard to their rural-urban distribution of population in Table-A.1.

Table A.1 Rural-Urban breakup of SC population 2011

\begin{tabular}{|l|l|l|l|l|l|l|l|}
\hline \multirow{2}{*}{$\begin{array}{l}\text { Sl. } \\
\text { No. }\end{array}$} & Schedule Caste & Urban & $\%$ & Rural & $\%$ & Total & $\%$ \\
\cline { 2 - 8 } & All Scheduled Caste & $4,05,560$ & 18.18 & $18,25,671$ & 81.82 & $22,31,321$ & 100 \\
\hline 2 & Bansphor & 4,840 & 29.59 & 11,519 & 70.41 & 16,359 & 100 \\
\hline 3 & Bhinrnali, Mali & 15,885 & 22.84 & 53,650 & 77.16 & 69,535 & 100 \\
\hline 4 & Dhupi, Dhobi & 15,813 & 30.16 & 36,618 & 69.84 & 52,431 & 100 \\
\hline 5 & Dugla, Dholi & 1,416 & 17.72 & 6,575 & 82.28 & 7,991 & 100 \\
\hline 6 & Hira & 7,853 & 14.20 & 47,447 & 85.80 & 55,300 & 100 \\
\hline 7 & Jalkeot & 7,298 & 29.46 & 17,476 & 70.54 & 24,774 & 100 \\
\hline 8 & Jhalo, Malo & 17,149 & 21.34 & 63,227 & 78.66 & 80,376 & 100 \\
\hline 9 & Kaibartta, Jaliya & $1,24,650$ & 17.98 & $5,68,569$ & 82.02 & $6,93,219$ & 100 \\
\hline 10 & Lalbegi & 195 & 24.68 & 595 & 75.32 & 790 & 100 \\
\hline 11 & Mahara & 563 & 30.90 & 1259 & 69.10 & 1,822 & 100 \\
\hline 12 & Mehtar, Bhangi & 5,938 & 67.20 & 2,897 & 32.80 & 8,835 & 100 \\
\hline 13 & Muchi, Rishi & 1,0691 & 13.76 & 66,952 & 86.24 & 77,643 & 100 \\
\hline 14 & Namasudra & 8,2359 & 13.04 & 54,9183 & 86.96 & $6,31,542$ & 100 \\
\hline 15 & Patni & 23,604 & 12.98 & $1,58,300$ & 87.02 & $1,81,904$ & 100 \\
\hline 16 & Sutradhar & 17132 & 25.83 & 49171 & 74.17 & 66303 & 100 \\
\hline
\end{tabular}

\subsection{SEX RATIO}

The sex ratio of the total SC population is 935, which is very close to the national average for SC's (936). Of the eleven major SC's low sex ratio has been registered among Muchi (916), Dhupi (920),
Jhalo (923), Jalkeot (923), Patni (924) and (955), BrittialBania (951), Sutradhar (938), and Bhuinmali (937).

\subsection{LITERACY \& EDUCATIONAL LEVEL}

Table-A.2 Literacy Rate among Major SC's

\begin{tabular}{|l|l|c|c|c|}
\hline \multirow{2}{*}{$\begin{array}{l}\text { Sl. } \\
\text { No. }\end{array}$} & \multirow{2}{*}{ Name of the Scheduled Caste } & \multicolumn{3}{|c|}{ Literate Rate (7 years \& above) } \\
\cline { 3 - 4 } & & Total & Male & Female \\
\hline 1. & All Scheduled Caste & 66.8 & 75.7 & 57.1 \\
\hline 2. & Bhuinmali & 72.2 & 79.8 & 64.0 \\
\hline 3. & Brittial Bania & 81.0 & 88.6 & 73.0 \\
\hline 4. & Dhupi & 76.0 & 83.1 & 68.3 \\
\hline 5. & Hira & 72.5 & 82.7 & 61.8 \\
\hline 6. & Jalkeot & 69.3 & 78.9 & 58.8 \\
\hline 7. & Kaibarta & 72.1 & 80.5 & 63.3 \\
\hline 8. & Jhalo & 52.8 & 64.3 & 40.3 \\
\hline 9. & Muchi & 47.9 & 70.1 & 34.2 \\
\hline 10. & Namasudra & 60.2 & 81.5 & 49.4 \\
\hline 11. & Patni & 75.9 & 76.6 & 69.9 \\
\hline 12. & Sutradhar & 67.2 & & 57.2 \\
\hline
\end{tabular}

\subsection{PROBLEMS AND PERSPECTIVE}

Traditionally the primary occupation of the Hiras was pottery making. This occupation is still in vogue among them. Their fore-fathers did not think much to posses agricultural land. Due to this, to-day they have no agricultural land. Moreover, the income from the pottery is gradually diminishing in the society due to widely use of aluminium and plastic products. Now, they have realized that income from the pottery making is insufficient to maintain the families. It is reported that at one time, the
Government of Assam had allotted 2 bighas of agricultural land to each family at Barpeta. Their residential plots are rent free. It was allotted to them by the Satra Committee on the condition that they are required to supply the necessary potteries to the Satraevery year for socio-religious ceremonies. This practice is still prevailing in the society. As the residential plots are owned by the Satra committee, they cannot dispose the land.

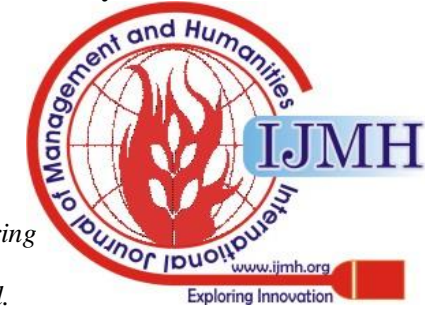


Besides the Satra, they have no other liabilities or contract with other caste groups in and around Barpeta.

Earlier, they used to sell their pots to their neighbouring communities on barter system. Now, this practice has completely vanished from the society. The Marnoi Hiras have a market link with the Bhutias and the Muslims of Goalpara and the villagers of the Garo hills. The olderfolk have reported to the researcher that they had a good link with the people of the erstwhile East Bengal in preIndependence era. After Independence, this market link has greatly affected their economy.

As the Hiras are not expertise in agricultural field they are not involved in share-cropping with other communities. In non-agricultural sector also they are not getting any Governmental help. Some of them are in Govt. and SemiGovt. jobs. They are not getting easily any loan from the Government to set up business. There is very few cooperative systemamong the Hiras to improve their traditional occupation. Right from the collection of raw materials to finished work, it is the duty of the individual family to carry out its own means.

Due to the lack of transport facility most of them sell their products at the site itself while some sell it at Barpeta, Guwahati, Nalbari and other neighbouring places. There are many Hira families are not willing to continue their traditional occupation. They now prefer for other jobs. It is difficult to ascertain here whether this preference is due to the poor economic condition, raising the caste statue or due to the Govt. new policy of self-employment. It is fact that the pottery making is no longer a lucrative job to maintain a family with the basic necessities of life.

Another important aspect of the Hiras is that the womenfolk in majority can't devote much time in their household activities due to active part in pottery making. It s reported that the womenfolk are mostly busy in the whole scenario of pot making. As such the mothers cannot properly nourish and nurture their children. Weaving is totally absent among them. Banking and postal facilities are inadequate in their areas. They have to come to town for banking and other official works. Due to the lack of financial institutions, the villagers are forced to take loan from the Local Mahajans (money-lenders) after mortgaging some valuable items like gold ornaments, metal and aluminium utensils.

\subsection{UPGRADATION AND IMPROVEMENT OF THE POTTERY INDUSTRY}

For upgradation and improvement of the pottery industry, modern technical methods are to be applied for acquirement of knowledge so that productivity and attraction of the products can be increased. To modify the designs of the finished products, the potters should be well trained up in the Pottery Training Centres outside Assam. In Karnataka, there is a Central Village Pottery Institute at Khanapur in the district Belgaum under the KVIC. In Maharashtra, such pottery institutes are found.

Hira potters of Assam should have training centres at local levels so that the poor potters also can be trained up to produce modern utensils and equipments. They should be encouraged by the State Government. On the whole, modern techniques for modification of the old handicrafts will bring heavy demand in the market and will make alive the pottery industry otherwise the Hira Cottage industry will be vanished in a short time and most of the Hira people belonging to the scheduled caste will be unemployed. It is hoped that attention of the Government of Assam will be drawn by the department of Industry. For upliftment of the said Cottage Industry, the government of Assam will have to take immediate and necessary steps in connection with- a) permanent settlement of Hira Reserves as mentioned above to allot them to the potters. b) permission to collect the waste dry woods of the forest areas for utilization in the pottery industry. c) creation of a good market for the products and d) training facility to each and every potter who is engaged in the industry.

\section{OBJECTIVES OF THE STUDY}

1. To study the social condition of Hiras which includes their population, sex ratio, education and literacy rate, women status in a society.

2. To study the economic condition of the Hiras which includes the present condition of Hira pottery industry, land holding pattern and income.

3. To suggest suitable measures for upgrading and improving the economic condition of Hira community.

\section{METHODOLOGY}

This study relies on data collection from primary and secondary sources and bringing out a theoretical analysis of collected resources. Data for the present study have been collected through intensive fieldwork. During fieldwork, data have been collected by employing various methods and techniques. In the beginning, some markets have been visited in order to gather information about the dwelling places of the Hira people. On the basis of their information, some villages of Assam have been visited frequently. Thereafter some reports have been made with some village leaders and some influential persons in order to interact with the locale people of this occupational community.

\section{RESULT OF THE STUDY}

The Hira potters have been carrying on this occupation and maintaining their livelihood since the past. They got a good earning from the pottery industry. In the ancient time the potters produced some particular pots for cooking and other use for the common people which have now been replaced by modern metallic utensils and equipment's found in the modern market. But in collaboration with experts and modern trained up designers, modification of the earthen pots in varieties has brought its heavy demand for each family. Hira people have become more idle and dependent on the Government and hence lagging behind. The people could be serve best under the general plan for Assam and this has been the responsibility of the Govt. of the State. The constitution has also directed to withdraw such a special plan for a special group of people on caste basis which hinders the growth of one nation and one caste in the country. This study help us to find out the present condition of Hira pottery industry, land holding pattern and their income. Moreover, this research project aims at collecting various methods for improving the socio-economic condition of Hira Community.

Published By:

Blue Eyes Intelligence Engineering \& Sciences Publication

DOI: 10.35940/ijmh.G0702.034720

Journal Website: www.ijmh.org

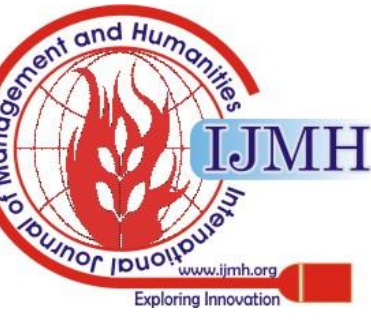




\section{CONCLUSION}

Numerically, the Hiras occupy the fifth position among the Scheduled Castes of Assam. The traditional occupation of pottery making is no longer a profitable one so that they are now facing a lot of economic hardship.. Their forefathers had declined to posses the agricultural land as they were happy with their own profession. In fact, they are now under the poverty line.

This poor economic condition can be improved if the Govt. takes some steps for agriculture. At the same time, inputs like seeds, fertilizers, irrigation facilities should be made available to them at the cheaper price. In this context, the allotment of land should be made in clusters so that the people can take advantage of many of the common facilities.

Another important aspect is that their occupation is an unorganized one so that it has caused many problems like loan facility, market and transport. Moreover, they are suffering from serious diseases. Therefore efforts should be made to improve their health and environmental condition so that they will not suffer from such diseases.

Education is another constraint for economic development. In this respect Government may give some compensation to the parents of the school going boys and girls. Government should appoint well educated teachers in every Government School. The people should be made realize that education is the only way to equip oneself for socio-economic development.

Over and above, the economic backwardness of the Hiras can be attributed to their low income occupation of pottery making. Its remedy requires a systematic effort from the Government and non-governmental organisations.

\section{REFERENCES}

1. Census of India Report, Govt. of India, Assam (1991, 2001,2011) Davidson, Percy, E. \& Anderson, H. Dewey. 1937

2. Occupation Mobility in an American Community. Stanford University Press, Huges, Everett, C. 1958

3. Man and their Work. Glencoe, III, The Free Press, Majumdar, D.N. \& Datta Ray, B. 1985

4. Tribal Occupational Mobility. Calcutta Research India Publication, Saraswati, B. \& Behura, N. 1966

5. Pottery Techniques in Present India. Calcutta. Anthropological Survey of India.Sharma Thakur, Cr.C. 1985

6. The Kaibartas of Assam: Some reflection on changing traditional occupation in two kaibarta villages of Jorhat District of Upper Assam. Bulletin of the Tribal Research Institute , Assam. Guwahati:1:V;33-44 Website referred- https://shodhganga.inflibnet.ac.in

\section{AUTHOR PROFILE}

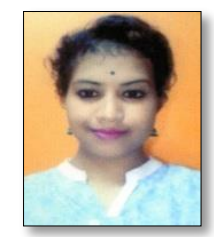

Barasha Rani Baishya, M.A. ,Gold Medallist, NET, SLET, Pursuing PhD degree on the topic of Schedule Caste Community of Assam under Cotton University.

Presented papers in several National and International Seminars and Workshops. Published article in journals. Publication of research article in Mobile No: 7578890046 IJSRP Journal. Publication of articles in ISBN.

Email:barashabaishya9737@gmail.com 